\title{
Surface Modification of Wool Fabric with Chitosan and Gamma Radiation
}

\author{
Md. Suhel Rana*, Md. Abdullah Al Mamun, Sajib Biswas, Md. Rifat Farabi Sourov \\ Department of Textile Engineering, Mawlana Bhashani Science and Technology University, Bangladesh
}

Copyright $(2017$ by authors, all rights reserved. Authors agree that this article remains permanently open access under the terms of the Creative Commons Attribution License 4.0 International License

\begin{abstract}
Surface modification of wool was done with chitosan, gamma radiation and combined chitosan/gamma radiation to analyze how polymer loading $\%, \mathrm{k} / \mathrm{s}$ value, dye uptake $\%$ and wash fastness property vary of the dyed fabric. In this investigation scoured and bleached knitted wool fabric was treated with $0.1 \%, 0.3 \%, 0.5 \%, 0.7 \%$ and $1 \%$ chitosan and polymer loading was found as of $1.21 \%, 1.38 \%$, $0.32 \%, 0.14 \%$ and $0.48 \%$ respectively. It was found that polymer loading $\%$ increase significantly with the decrease of chitosan concentration $\%$ up to a certain limit. Some samples were irradiated with $5 \mathrm{kGy}, 10 \mathrm{kGy}, 20 \mathrm{kGy}$ and $50 \mathrm{kGy}$ gamma radiation individually. Combined chitosan/gamma treatment was carried out by treating with $0.1 \%$ chitosan followed by treatment with $5 \mathrm{kGy}, 10 \mathrm{kGy}$, $20 \mathrm{kGy}$ and $50 \mathrm{kGy}$ gamma radiation. The infrared spectrum of wool specimens were analyzed by Fourier Transform Infrared Spectrometer (FT-IR). It was found that the infrared spectrum of untreated and treated wool specimens were approximately same except the peak absorbs at 1340-1265 $\mathrm{cm}^{-1}$ which indicate the C-N stretch absorption of aromatic amines. After dyeing $\mathrm{k} / \mathrm{s}$ value of untreated and treated wool specimens were measured using Data color $600^{\circledR}$. There was a remarkable variation of $\mathrm{k} / \mathrm{s}$ value on different treatment process. Dye uptake $\%$ of untreated and treated wool specimens were determined by using UV Visible Spectrophotometer in terms of absorbency. Color fastness to wash was measured using ISO standard. There was no significant change of wash fastness property of treated and untreated wool.
\end{abstract}

Keywords Wool Fabric, Chitosan, Gamma Radiation, Polymer Loading, Fixation, Dye Uptake

\section{Introduction}

Modification is generally used to designate a deliberate change in composition or structure leading to an improvement in different type of fiber properties. Surface modification of the polymeric fibers without changing the mass properties has been a classical research topic for many years which is now widespread studies as new applications of polymeric materials develop, particularly in the fields of biotechnology, bio-engineering, and recently in nanotechnology. [1] Surface modification is the unite insertion of physics and chemistry together to modify material to promote surface properties [2].

Wool is a protein fiber which is utilized for suiting, shawl, cover and covers, however it has distinct demerits like shrinkage in order to presence of cuticle scales on the surface of the fiber. Research works subsequent to 1950 have been done to determine those issues by various techniques.[3] Surface of a fiber has a significant effect on overall processing properties of that fiber. In wool fabric, modification of the outer epicuticle and executable imparts lucrative improvement to wool like dye ability, printability, and wettability.[4] Major part of wool fiber is protein named keratin which is consists of two major morphological parts: cortex cells (90\% of the wool's weight) and the adjacent cuticle cells (10\% of the wool's weight). The surface of the cuticle cells exceptionally hydrophobic because of covalently bound fatty acids [5].

The morphology of the wool fiber surface assumes a vital part in textile finishing processes. The covalently bound unsaturated fats and the high measure of di-sulfide bridges make the external wool surface exceedingly hydrophobic. Particularly in the printing and dyeing of wool, the hydrophobic character of the wool surface is irritating. Dispersion of the hydrophilic dye into the fiber is blocked [6]. For this reason, the dye ability and hydrophilicity properties of the wool fiber should be developed.

An acid dye is a salt of a carboxylic, sulfuric or phenolic organic acid. The salts are mostly sodium or ammonium salts. Acid dyes are commonly solvent in water and foster affinity for protein fibers. During dyeing, ionic bonding with fiber cationic sites represent fixation of colored anions in the dyed material. Animal protein fibers and synthetic nylon fibers contain many cationic sites. There is a fascination of anionic dye particle to a cationic site on the fiber. The strength (fastness) of this bond is identified with the propensity of the dye to remain dissolved in water over fixation to the fiber.[7] 
Chitosan is a nontoxic and biodegradable biopolymer sufficiently found in natural source, particularly in the exoskeletons of shell arthropods and mollusks as well as the cell wall of certain fungi in the form of chitin. Chitin deacetylates in alkaline solution to obtain chitosan. The organic name of chitosan is $\beta$-(1-4)-2-amino-2-deoxyD-glucopyranose. [8]

Chitosan is composed two main functional groups, namely hydroxyl and amino groups as well as ether linkages. Chitosan and cellulose have analogous structure with the same $\beta$-glucoside linkages and the main discrepancy is the presence of primary amino groups at the greater part of the $\mathrm{C}-2$ position in chitosan, in place of the hydroxyl groups in cellulose.[9] Chitosan has primary amino groups in its structure and the number of these amino groups is related to the rate of antimicrobial activity. The acquaintance of asparagine to chitosan oligosaccharide significantly enhanced the bactericidal activity and least inhibitory concentration. This is the probable indication of the higher the number of amino groups, the higher the antimicrobial activity. [10] The possibility to modify textile fibers (natural or man-made) with chitosan by means of impregnation improves the mechanical properties of such treated textiles; their staining behavior, water resistance, electro conductivity, and adds bioactive, as well as bacteriostatic behavior. [11] Chitosan treated wool showed a better dye ability. [12]

Pretreatment of $100 \%$ wool fabric with alkaline peroxide enhance the adsorption of chitosan. This adsorbed chitosan improve the dyeing rate, $\mathrm{k} / \mathrm{s}$ value, fastness property, wettability and shrink resistance properties of wool [13]. Chitosan present on wool surface can easily attract and interacts with the dyestuff, so that it improves the dyeing rate reducing dyeing time. So it is considered as a dominating dyeing site on wool fiber surface.[14, 15]

Plasma treated wool show better dye ability and good washing, rubbing and light fastness property. Plasma treatment improve the absorption of cationic dye to wool fiber.[16] Low Plasma treated wool using oxygen, argon, and their mixture improve the dye ability of wool fiber.[17]

Gamma radiation has the littlest wavelengths and the most vitality of any wave in the electromagnetic spectrum. Textile material assimilate electromagnetic radiation of changing wavelength in the visible range of spectrum.[18] Treatment with combined uvlozone and different chitosan concentrations on wool increase $\mathrm{k} / \mathrm{s}$ and L.F. values (i.e. improving the dye ability) of the treated samples compared with the untreated dyed ones due to increasing the hydrophilicity of the treated fibers.[19]

\section{Materials and Methods}

\subsection{Materials}

\subsubsection{Fabric}

A single jersey fabric of 160 GSM (Grams Per Square-meter), knitted from 100\% wool yarn, was collected from French Fashions Knitting Pvt. Ltd. (a sister concern of
MOUNTAGUT GROUP), AEPZ, Narayangonj, Bangladesh.

\subsubsection{Chemicals}

$\mathrm{Na}_{2} \mathrm{CO}_{3}$ was used as scouring agent and $\mathrm{H}_{2} \mathrm{O}_{2}$ was applied as bleaching agent. Lab grade Stabilizer, detergent and sequestering agent were used as auxiliary chemicals.

Chitosan, collected from IRPT, Bangladesh Atomic Energy Research Commission, Savar, Dhaka, Bangladesh, was used as cationizing agent. To dissolve this chitosan Acetic acid was applied.

Best Acid Red A2B NEW was collected from DYSIN-CHEM. LIMITED, Dhaka, Bangladesh. $\mathrm{H}_{2} \mathrm{SO}_{4}$ was used to maintain the $\mathrm{pH}$ of dye bath collected from lab. ISO (International Organization of standardization) reference detergent and Soda ash (Merck, Germany) was used for assessing color fastness to wash.

\subsection{Methodology}

\subsubsection{Sampling}

The fabric was cut into some specimens of two different sizes. Half of the total no. of specimens was of $6 \times 6 \mathrm{~cm}$ while the rest half were of $10 \times 10 \mathrm{~cm}$.

\subsubsection{Scouring and Bleaching of Wool}

Firstly the specimens were immersed into the below mentioned solution overnight using Material to Liquor ratio 1: 10 .

\begin{tabular}{|c|c|}
\hline Detergent (Felson NOF) & $: 2 \mathrm{~g} / \mathrm{L}$ \\
\hline $\mathrm{Na}_{2} \mathrm{CO}_{3}$ & $: 5 \mathrm{~g} / \mathrm{L}$ \\
\hline $\mathrm{H}_{2} \mathrm{O}_{2}$ & $: 6 \mathrm{~g} / \mathrm{L}$ \\
\hline Stabilizer(Sodium Silicate) & $: 1.5 \mathrm{~g} / \mathrm{L}$ \\
\hline Sequestering agent & $: 1 \mathrm{~g} / \mathrm{L}$ \\
\hline Temp. & $: 60^{\circ} \mathrm{C}$ \\
\hline Time & $: 80 \mathrm{~min}$ \\
\hline
\end{tabular}

Then single-bath Scouring and bleaching was carried out in Gyrowash machine at $60^{\circ} \mathrm{C}$ for 80 minutes.

\subsubsection{Treatment of Wool with Chitosan}

Some of the scoured and bleached specimens were treated with $0.1 \%, 0.3 \%, 0.5 \%, 0.7 \%$ and $1 \%$ chitosan solution at $60^{\circ} \mathrm{C}$ for 30 minutes, using exhaust method, in IR Dyer. These Chitosan of different concentrations solutions were prepared using $1 \%$ acetic acid and was stirred for $30 \mathrm{~min}$ to ensure chitosan was dissolved thoroughly.

\subsubsection{Treatment of Wool with Gamma Radiation}

Some of the scoured and bleached specimens were irradiated with Cobalt-60 gamma radiation from IFRB, Bangladesh Atomic Energy Research Commission, Savar, Dhaka, Bangladesh at a dose rate of $5 \mathrm{kGy}$ per hour. These Samples were irradiated as 5kGy, 10kGy, 20kGy and $50 \mathrm{kGy}$ individually. 
Some of the $0.1 \%$ Chitosan treated specimens were also irradiated with $5 \mathrm{kGy}, 10 \mathrm{kGy}, 20 \mathrm{kGy}$ and $50 \mathrm{kGy}$ gamma radiation individually.

\subsubsection{Dyeing Process of Treated and Untreated Wool}

All the Treated and Untreated specimens were dyed, in IR Dryer, with $1 \%$ Best Acid Red $\mathrm{A} 2 \mathrm{~B}$ New at $100^{\circ} \mathrm{C}$ for 30min using 1:10 Material to Liquor ratio. $1 \mathrm{~g} / \mathrm{L} \mathrm{H}_{2} \mathrm{SO}_{4}$ was used to maintain $\mathrm{pH}(3-4)$ of each dye bath during dyeing process. Then washing was done at $80^{\circ} \mathrm{C}$ for $10 \mathrm{~min}$ with $1 \mathrm{~g} / \mathrm{L}$ soaping agent.

\subsubsection{Determination of polymer loading}

Average oven dry weight of untreated and chitosan treated specimens were calculated. Then polymer loading $\%$ of each specimens were determined using following formula:

$$
\text { Polymer loading } \%=\left(\mathrm{W}_{2}-\mathrm{W}_{1}\right) / \mathrm{W}_{1} \times 100 \%
$$

Here,

$\mathrm{W}_{1}=$ Average oven dry weight of untreated sample.

$\mathrm{W}_{2}=$ Average oven dry weight of sample after treatment.

\subsubsection{FT-IR (Fourier Transform Infrared Spectrometer) Analysis}

Modification of wool was estimated by using FT-IR spectrophotometer. The infrared spectrum of untreated, $0.1 \%$ chitosan treated, $10 \mathrm{kGy}$ gamma radiation treated and combined $0.1 \%$ chitosan and $10 \mathrm{kGy}$ gamma radiation treated wool specimens were measured using SHIMADZU FT-IR spectrophotometer, Japan, in spectra range 4000-500 $\mathrm{cm}^{-1}$ using $\mathrm{KBr}$ disc technique.

\subsubsection{Determination of Color Strength}

The reflectance value of each dyed specimen for the wavelength range of $400-700 \mathrm{~nm}$ (with $10 \mathrm{~nm}$ intervals) was found using Datacolor $600^{\circledR}$ spectrophotometer. By using this reflectance value in the Kubelka Munk's equation the value of color strength $(\mathrm{k} / \mathrm{s})$ was calculated:

$$
\text { Color strength }(\mathrm{k} / \mathrm{s})=(1-\mathrm{R})^{2} / 2 \mathrm{R}
$$

Here,

$\mathrm{R}=$ Reflectance

\subsubsection{Determination of Dye Uptake\%}

Absorbency of original dyeing solution, Treated and Untreated wool specimens' dyeing effluent solution were measured by UV Visible Spectrophotometer. Dye uptake\% of untreated and treated wool was calculated using following formula:

$$
\text { Dye uptake } \%=\left(\mathrm{A}_{0}-\mathrm{A}_{1}\right) / \mathrm{A}_{0} \times 100 \%
$$

Here,

$\mathrm{A}_{0}=$ Maximum absorbency of dye liquor before dying.

$\mathrm{A}_{1}=$ Maximum absorbency of dye liquor after dyeing.

\subsubsection{Determination of Color Fastness to Wash}

To determine color fastness to wash ISO 105 C04 method was followed.

\section{Results and Discussion}

\subsection{Fourier Transform Infrared Spectrometer Analysis of Wool}

FT-IR had been utilized to determine the impact of the different treatment process on the properties of the diverse capacity bunches and also to determine the diverse amino acids present in wool. An infrared spectrometer decides the positions and relative sizes of the considerable number of ingestions or tops in the infrared area and plots them on a bit of paper. This plot of retention power (transmittance) versus wave number is alluded to as the infrared range of the compound. The infrared spectrum of untreated, $0.1 \%$ chitosan treated, $10 \mathrm{kGy}$ gamma treated and combined $0.1 \%$ chitosan and 10kGy gamma treated are studied here from Figures 1 to 4.

It is found that the infrared spectrum of untreated and treated wool sample are approximately same except the peak absorb at $1340-1265 \mathrm{~cm}^{-1}$ which indicate the C-N stretch absorption of aromatic amines.[20] Bend stretch $1338.60 \mathrm{~cm}^{-1}$ is only found in treated specimens while the stretch is absent in untreated specimen. This phenomenon justifies the surface modification of wool. 


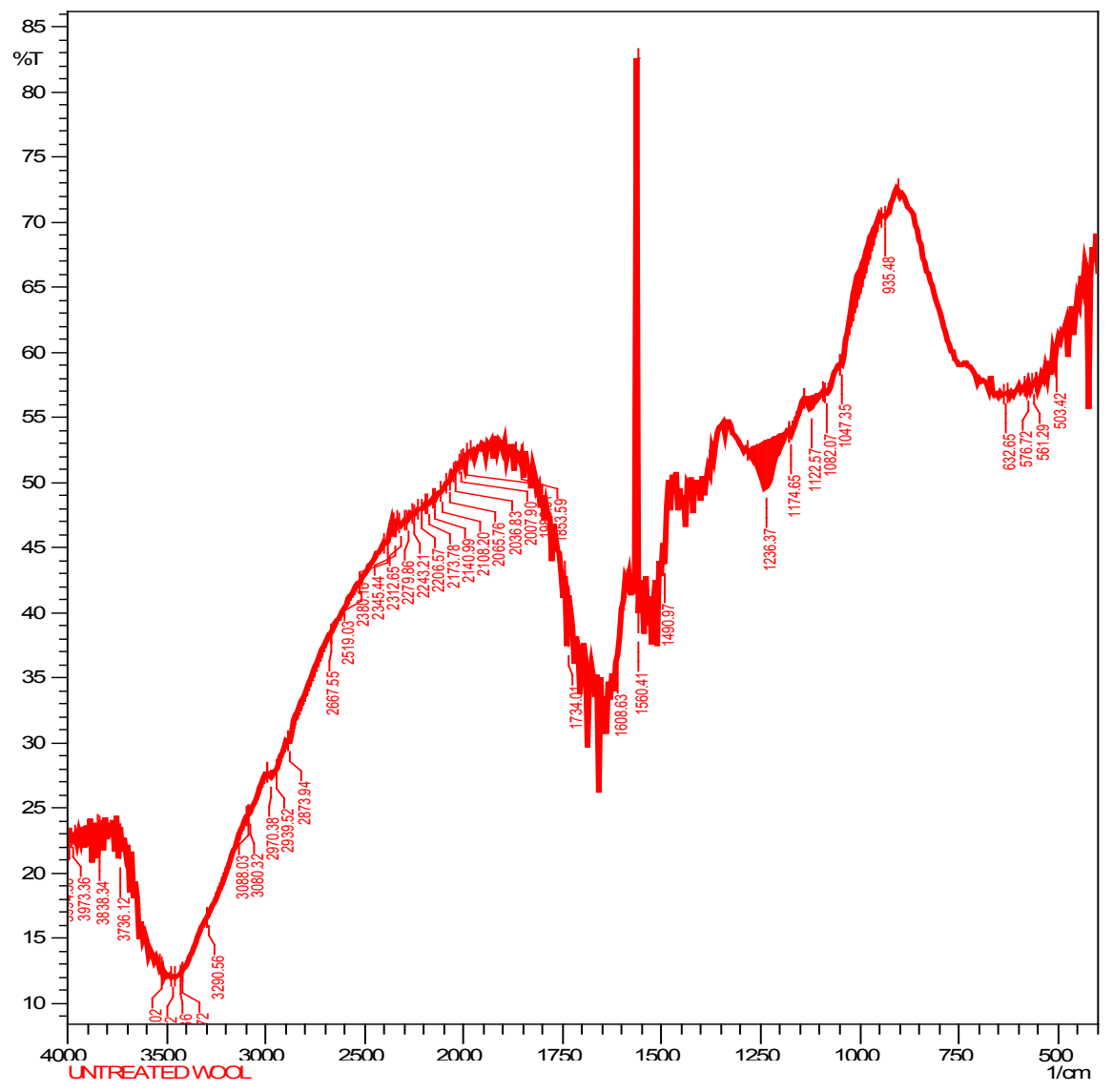

Figure 1. The infrared spectrum of untreated wool

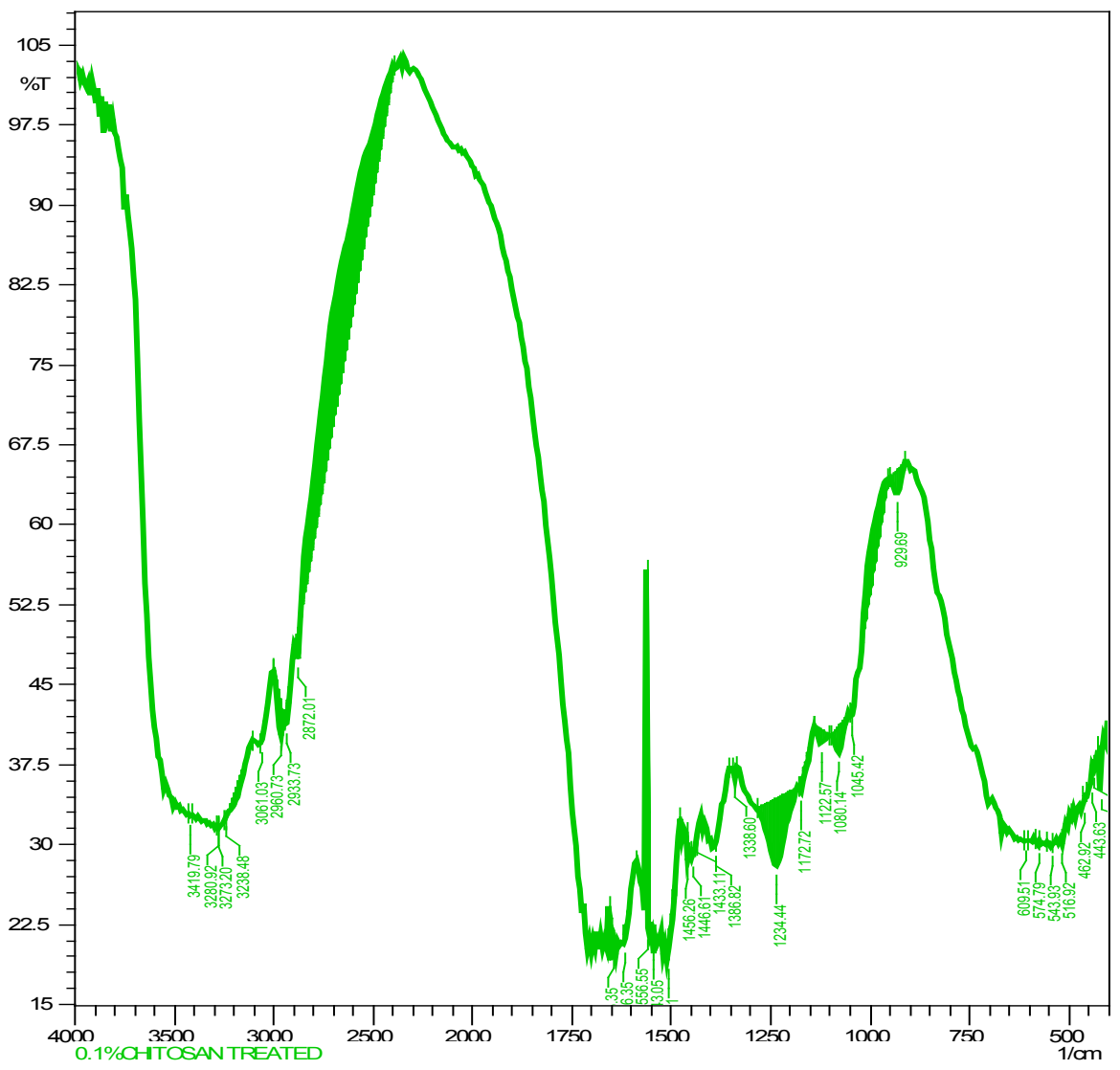

Figure 2. The infrared spectrum of $0.1 \%$ chitosan treated wool 


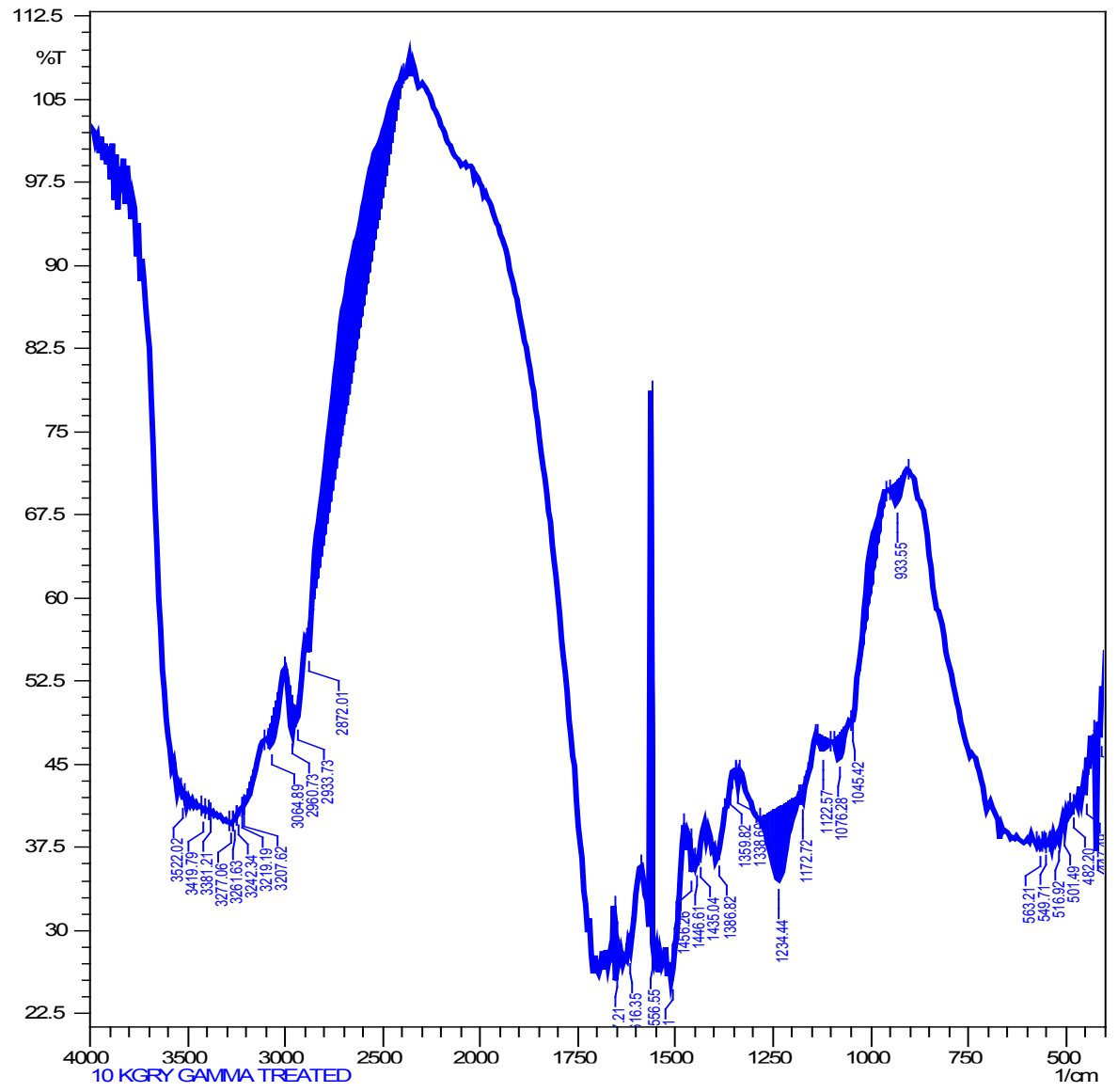

Figure 3. The infrared spectrum of $10 \mathrm{kGy}$ gamma treated wool

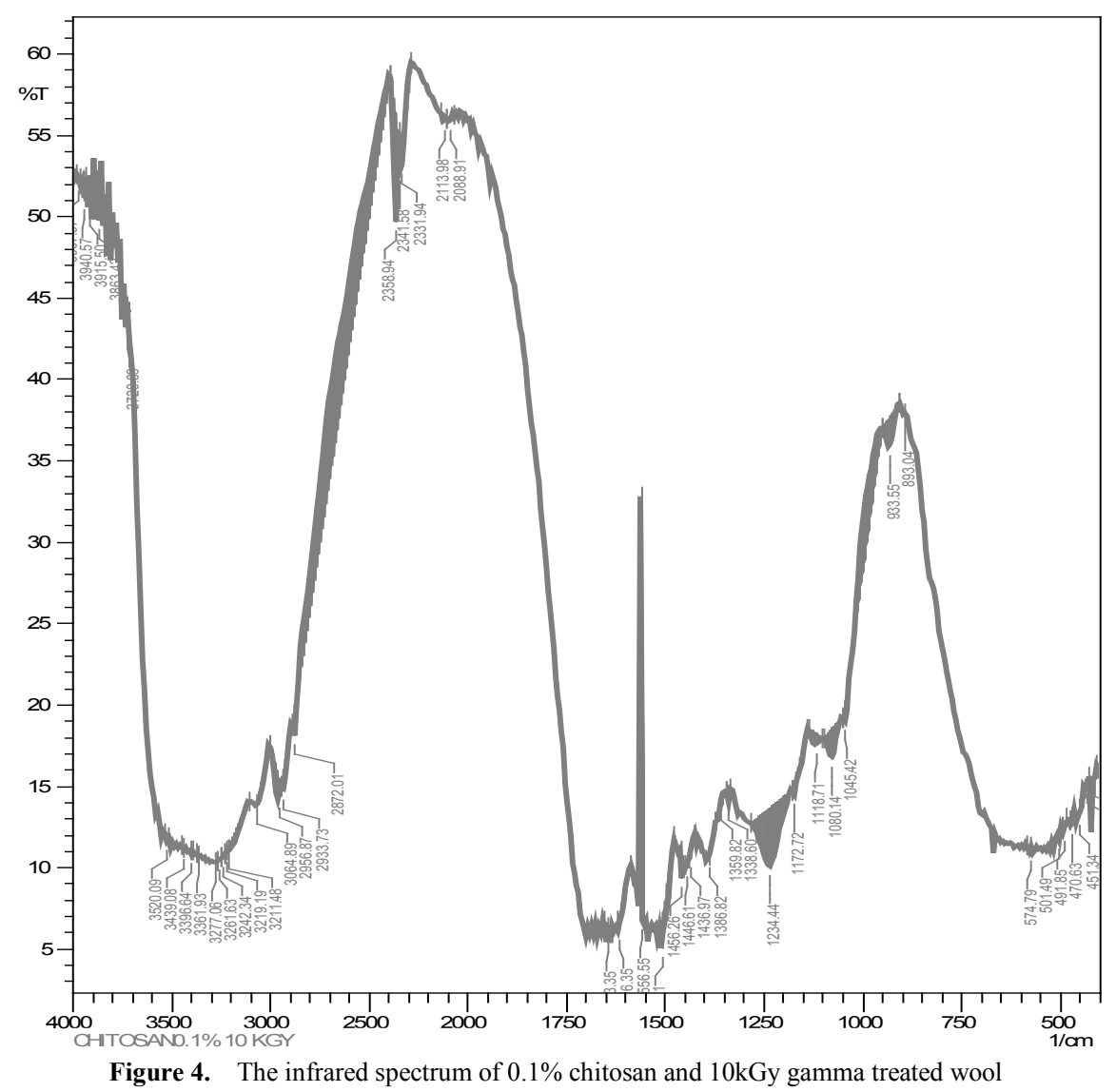




\subsection{Analysis of Polymer Loading}

Polymer loading \% of the wool specimens treated with different concentration of chitosan is shown in Table 1.

By plotting a diagram using the value of chitosan concentration \% on $\mathrm{X}$-axis and respective polymer loading \% on $\mathrm{Y}$ axis-

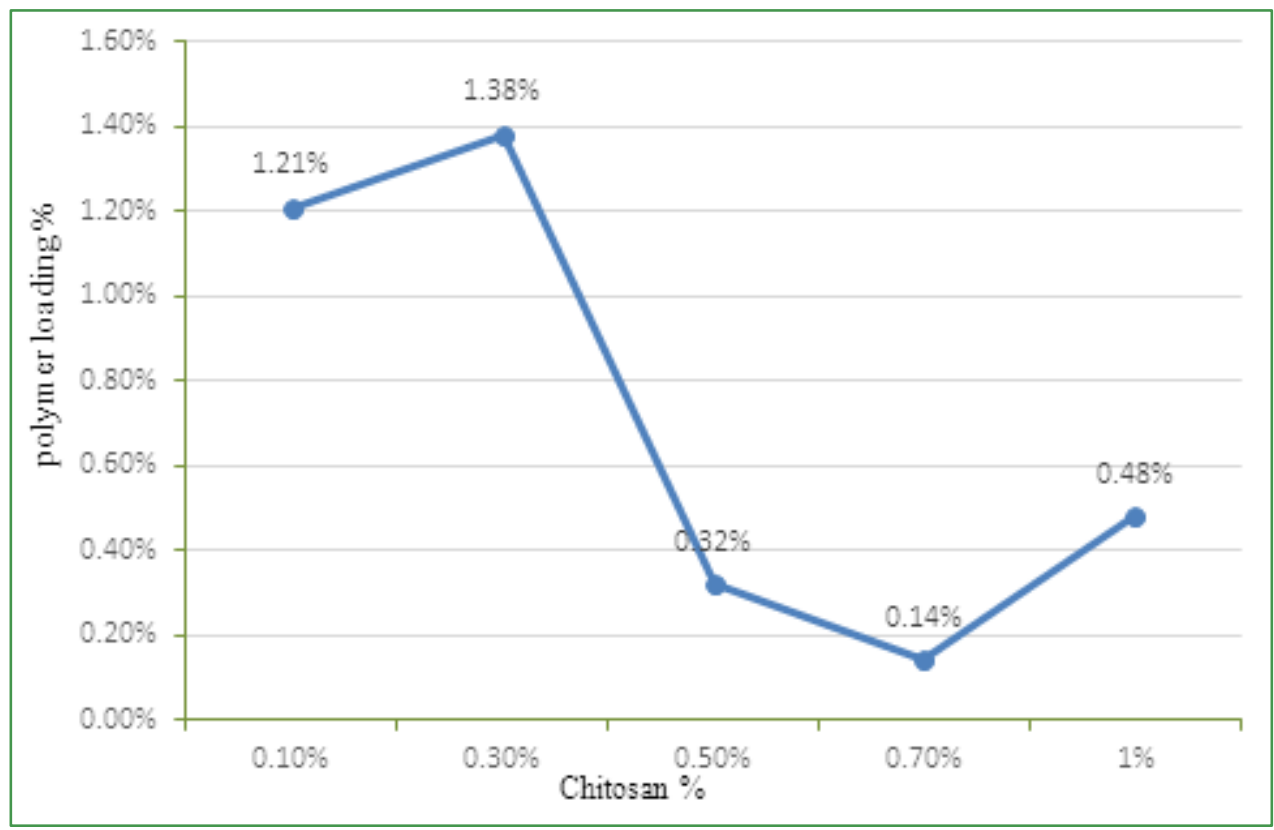

Figure 5. Polymer loading $\%$ of different chitosan concentration treated wool specimens.

Table 1. Polymer loading $\%$ of different chitosan concentration treated wool specimens

\begin{tabular}{|c|c|c|c|c|c|}
\hline $\begin{array}{l}\text { Fabric } \\
\text { type }\end{array}$ & $\begin{array}{c}\text { Chitosan } \\
\text { concentration } \\
(\%)\end{array}$ & $\begin{array}{c}\text { Average } \\
\text { weight before } \\
\text { treatment }\left(\mathrm{W}_{1}\right)\end{array}$ & $\begin{array}{c}\text { Average } \\
\text { weight after } \\
\text { treatment }\left(\mathrm{W}_{2}\right)\end{array}$ & $\begin{array}{l}\left(\mathrm{W}_{2}-\mathrm{W}_{1}\right) \div \\
\mathrm{W}_{1} \times 100 \%\end{array}$ & $\begin{array}{c}\text { Average polymer } \\
\text { loading \% }\end{array}$ \\
\hline \multirow{2}{*}{1} & \multirow{2}{*}{$0.10 \%$} & 5.001 & 5.063 & $1.23 \%$ & \multirow{2}{*}{$1.21 \%$} \\
\hline & & 11.303 & 11.438 & $1.19 \%$ & \\
\hline \multirow{2}{*}{2} & \multirow{2}{*}{$0.30 \%$} & 4.198 & 4.255 & $1.35 \%$ & \multirow{2}{*}{$1.38 \%$} \\
\hline & & 11.809 & 11.976 & $1.41 \%$ & \\
\hline \multirow{2}{*}{3} & \multirow{2}{*}{$0.50 \%$} & 3.787 & 3.802 & $0.39 \%$ & \multirow{2}{*}{$0.32 \%$} \\
\hline & & 12.317 & 12.348 & $0.25 \%$ & \\
\hline \multirow{2}{*}{4} & \multirow{2}{*}{$0.70 \%$} & 4.734 & 4.738 & $0.11 \%$ & \multirow{2}{*}{$0.14 \%$} \\
\hline & & 11.611 & 11.631 & $0.17 \%$ & \\
\hline \multirow{2}{*}{5} & \multirow{2}{*}{$1.00 \%$} & 3.877 & 3.899 & $0.55 \%$ & \multirow{2}{*}{$0.48 \%$} \\
\hline & & 12.268 & 12.319 & $0.41 \%$ & \\
\hline
\end{tabular}

It is found that polymer loading \% increase significantly with the decrease of chitosan concentration up to a certain limit. The lowest polymer loading $\%, 0.14$ is found in $0.7 \%$ chitosan treated specimen.

\subsection{Analysis of Color Strength $(\mathrm{k} / \mathrm{s})$}

Different specimens are expressed in the symbols showed in the below mentioned table- 
Table 2. Designation of specimens

\begin{tabular}{|c|c|}
\hline Code & Test fabric type \\
\hline $\mathrm{U}$ & Untreated \\
\hline $\mathrm{A}$ & $0.10 \%$ Chitosan treated \\
\hline $\mathrm{B}$ & $0.30 \%$ Chitosan treated \\
\hline $\mathrm{C}$ & $0.50 \%$ Chitosan treated \\
\hline $\mathrm{D}$ & $0.70 \%$ Chitosan treated \\
\hline $\mathrm{E}$ & $1 \%$ Chitosan treated \\
\hline $\mathrm{R}_{1}$ & $5 \mathrm{kGy}$ Gamma radiation treated \\
\hline $\mathrm{R}_{2}$ & $10 \mathrm{kGy}$ Gamma radiation treated \\
\hline $\mathrm{R}_{3}$ & $20 \mathrm{kGy}$ Gamma radiation treated \\
\hline $\mathrm{R}_{4}$ & $50 \mathrm{kGy}$ Gamma radiation treated \\
\hline $\mathrm{A} \mathrm{R}_{1}$ & $0.10 \%$ Chitosan $+5 \mathrm{kGy}$ Gamma radiation treated \\
\hline $\mathrm{A} \mathrm{R}_{2}$ & $0.10 \%$ Chitosan $+10 \mathrm{kGy}$ Gamma radiation treated \\
\hline $\mathrm{A} \mathrm{R}_{3}$ & $0.10 \%$ Chitosan $+20 \mathrm{kGy}$ Gamma radiation treated \\
\hline $\mathrm{A} \mathrm{R}_{4}$ & $0.10 \%$ Chitosan $+50 \mathrm{kGy}$ Gamma radiation treated \\
\hline
\end{tabular}

The effect of chitosan, gamma radiation, combined chitosan and gamma radiation on $\mathrm{k} / \mathrm{s}$ value of all the specimens dyed with Best Acid Red A2B New is shown in Table 3.

$\mathrm{K} / \mathrm{s}$ values of untreated and only chitosan treated specimens are demonstrated in Figure 6.

Table 3. Variation of $\mathrm{k} / \mathrm{s}$ value of treated and untreated wool specimens

\begin{tabular}{|c|c|c|c|c|}
\hline Fabric type & $\mathrm{L}^{*}$ & $\mathrm{C}^{*}$ & $\mathrm{~h}^{*}$ & $\mathrm{k} / \mathrm{s}$ value \\
\hline $\mathrm{U}$ & 40.117 & 50.828 & 2.661 & 12.8 \\
\hline A & 38.447 & 50.227 & 2.412 & 14.0 \\
\hline B & 38.257 & 50.829 & 2.626 & 14.4 \\
\hline $\mathrm{C}$ & 39.900 & 51.004 & 1.892 & 12.8 \\
\hline D & 40.087 & 51.535 & 2.501 & 12.8 \\
\hline $\mathrm{E}$ & 38.455 & 50.889 & 3.424 & 14.2 \\
\hline $\mathrm{R}_{1}$ & 38.414 & 50.163 & 2.993 & 14.1 \\
\hline $\mathrm{R}_{2}$ & 37.729 & 50.236 & 3.077 & 15.0 \\
\hline $\mathrm{R}_{3}$ & 39.283 & 49.863 & 2.923 & 13.1 \\
\hline $\mathrm{R}_{4}$ & 39.619 & 48.809 & 2.204 & 12.5 \\
\hline $\mathrm{A} \mathrm{R}_{1}$ & 37.988 & 49.770 & 2.378 & 14.3 \\
\hline $\mathrm{A} \mathrm{R}_{2}$ & 39.139 & 50.372 & 2.126 & 13.7 \\
\hline $\mathrm{A} \mathrm{R}_{3}$ & 39.129 & 49.888 & 2.124 & 13.1 \\
\hline $\mathrm{A} \mathrm{R}_{4}$ & 38.287 & 47.516 & 2.197 & 13.0 \\
\hline
\end{tabular}




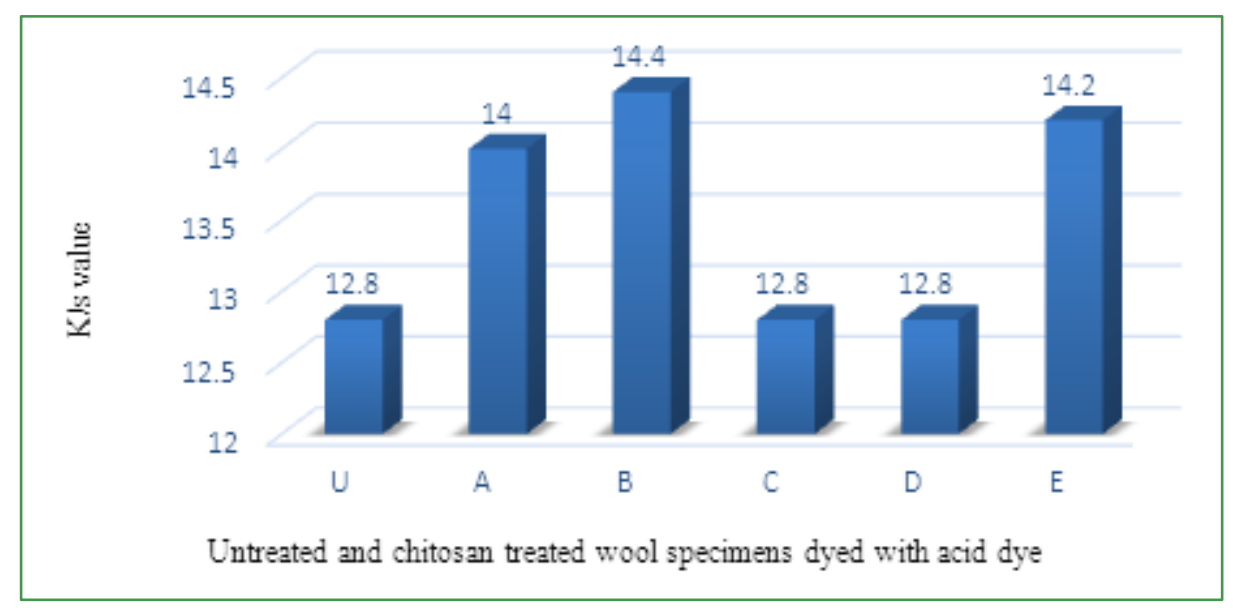

Figure 6. $\mathrm{k} / \mathrm{s}$ value of untreated and chitosan treated wool

Figure 6 manifest that $\mathrm{k} / \mathrm{s}$ value of untreated specimen is 12.8 and it culminated up to 14.4 which were found in $0.3 \%$ chitosan treated specimen. Thereafter a sudden fall of $\mathrm{k} / \mathrm{s}$ value, 12.8 is found in $0.5 \%$ and $0.7 \%$ chitosan treated specimens. Both of these very specimens contain the lowest polymer loading \%, showed in Figure 5.

Now, k/s values of untreated and only gamma radiation treated specimens are demonstrated in Figure 7.

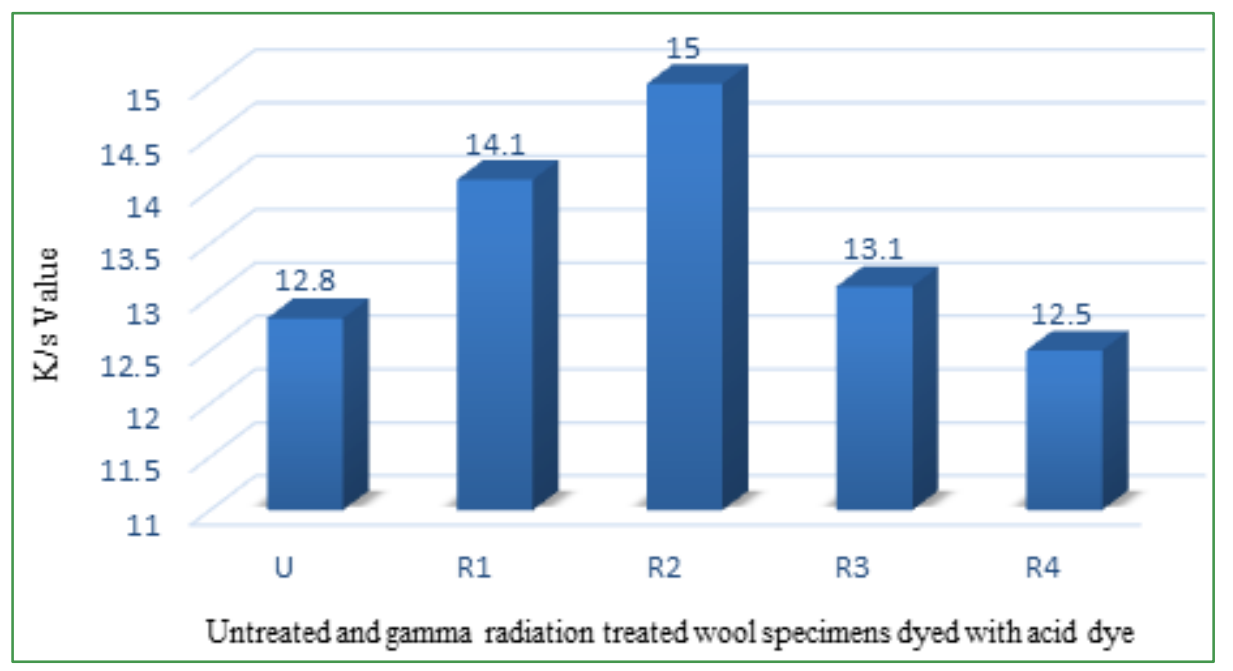

Figure 7. $\mathrm{k} / \mathrm{s}$ value of untreated and gamma radiation treated wool specimens

In general, $\mathrm{k} / \mathrm{s}$ value elevated up to 15 at $10 \mathrm{kGy}$ gamma radiation treated specimen. But from there $\mathrm{k} / \mathrm{s}$ value steadily decreased with the increase of gamma radiation. 8

Again $\mathrm{k} / \mathrm{s}$ values of untreated and combined $0.1 \%$ chitosan and gamma radiation treated specimens are depicted in Figure

From the Figure 8 , it is apparent that the $\mathrm{k} / \mathrm{s}$ value steadily decreases with the increase of gamma radiation in the $0.1 \%$ chitosan treated specimens. 


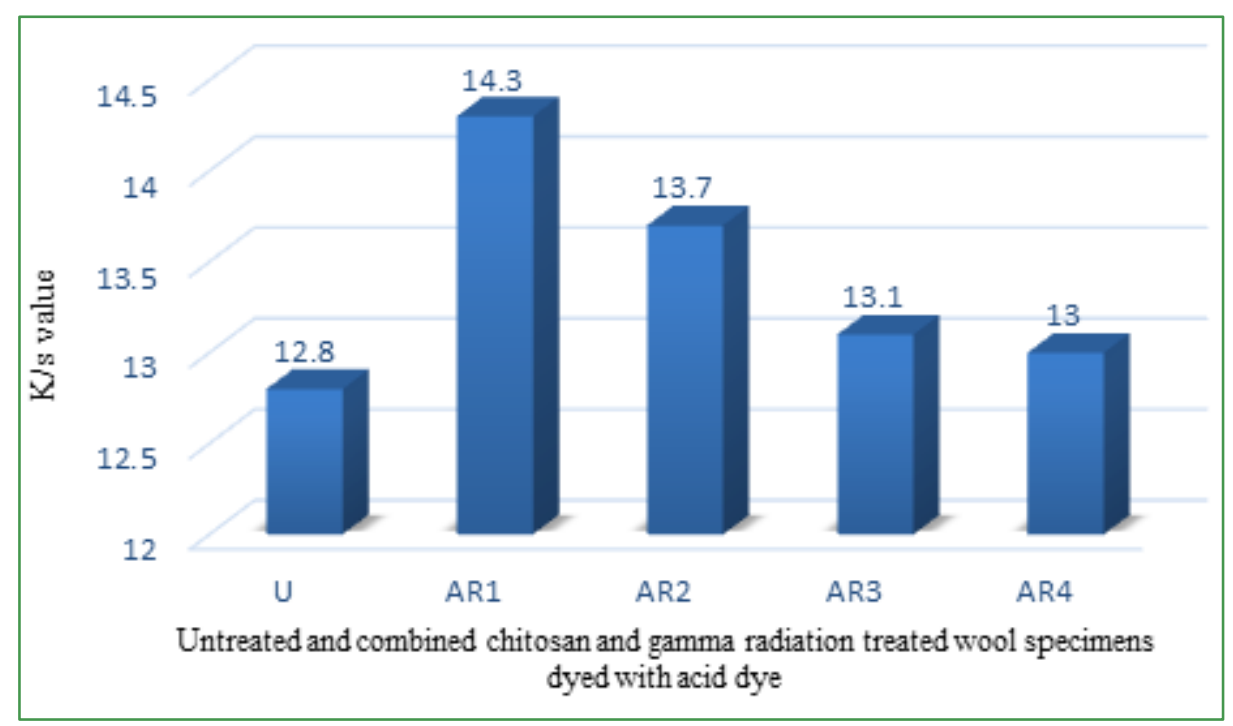

Figure 8. $\mathrm{k} / \mathrm{s}$ value of untreated and combine $0.1 \%$ chitosan and gamma radiation treated wool specimens

\subsection{Analysis of Dye Uptake\%}

Dye uptake \% of all the treated and untreated wool specimens are shown in Figure 9.

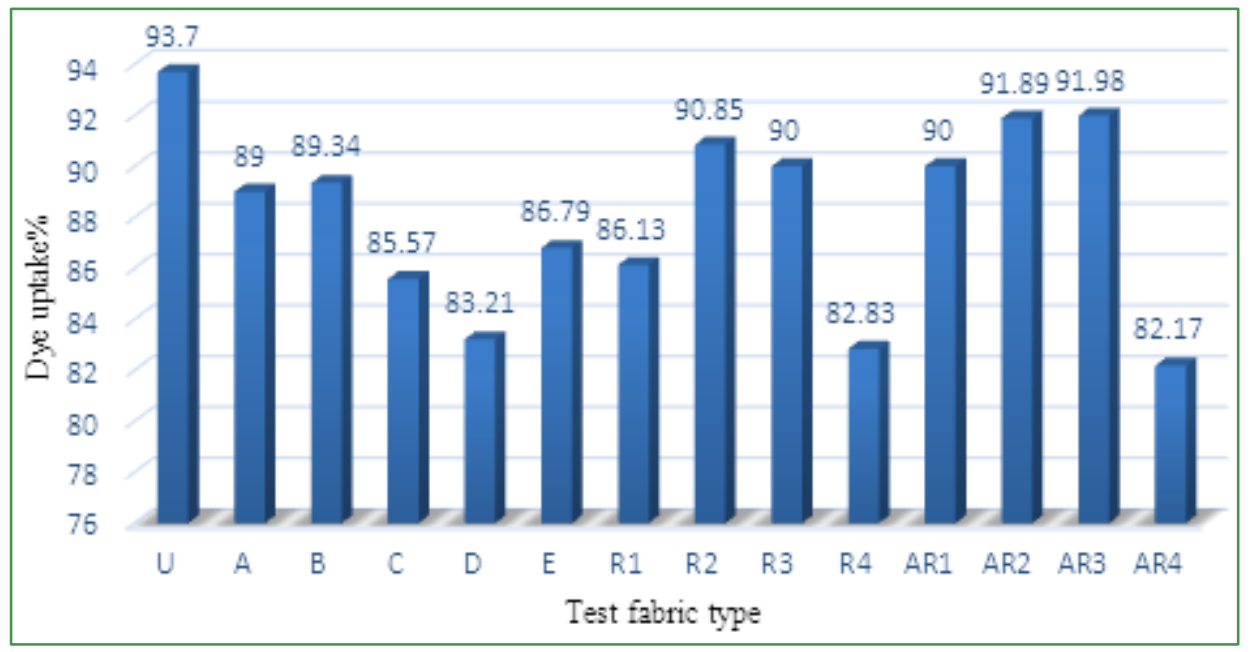

Figure 9. Dye uptake \% treated and untreated wool specimens

From the bar graph, all of the treated specimens had identical dye uptake $\%$ in a gradual variation such like $\mathrm{k} / \mathrm{s}$ value. In case of untreated specimen dye uptake \% was highest, but the $\mathrm{k} / \mathrm{s}$ value this untreated specimen was found to be lower than any other treated specimens except 50kGy gamma radiation treated specimen.

\subsection{Analysis of Color Fastness to Wash}

Color fastness to wash of all the treated and untreated specimens are shown in Table 4.

From Table 4 it is found that there is no noticeable variation of color fastness to wash of treated and untreated wool specimen.
Table 4. Color fastness to wash of treated and untreated wool

\begin{tabular}{|c|c|c|}
\hline Fabric type & Color change & Color staining \\
\hline U & $4-5$ & $3-4$ \\
\hline$A$ & $4-5$ & $4-5$ \\
\hline$B$ & $4-5$ & $4-5$ \\
\hline C & $4-5$ & $4-5$ \\
\hline$D$ & $4-5$ & 4 \\
\hline$E$ & $4-5$ & 4 \\
\hline$R_{1}$ & $4-5$ & $4-5$ \\
\hline$R_{2}$ & $4-5$ & $4-5$ \\
\hline$R_{3}$ & $4-5$ & 4 \\
\hline$R_{4}$ & 4 & $3-4$ \\
\hline $\mathrm{A} \mathrm{R}_{1}$ & $4-5$ & $4-5$ \\
\hline $\mathrm{A} \mathrm{R}_{2}$ & $4-5$ & $4-5$ \\
\hline $\mathrm{A} \mathrm{R}_{3}$ & $4-5$ & 4 \\
\hline $\mathrm{A} \mathrm{R}_{4}$ & 4 & $3-4$ \\
\hline
\end{tabular}




\section{Conclusions}

Chitosan treated wool specimens had satisfactory results on $\mathrm{k} / \mathrm{s}$ value of dyed sample. The higher the polymer loading $\%$ is, the higher the $\mathrm{k} / \mathrm{s}$ value will be. The $\mathrm{k} / \mathrm{s}$ value of gamma treated specimens increased up to $10 \mathrm{kGy}$ then it decreased with the increase of irradiation rate. FT-IR analysis shows the effectiveness of different treatment techniques. Although the dye exhaustion of untreated specimen was highest, the fixation was the lowest. Thus, the treated specimens comparatively had higher fixation despite having lower exhaustions. From the above facts it can be concluded that modification of wool fiber with chitosan and gamma radiation increases the dye fixation without some exceptions. There was no noticeable variation of wash fastness property of treated and untreated wool specimens.

\section{Acknowledgements}

Author would like to convey special thanks to department of textile Engineering, Mawlana Bhashani Science and Technology University and Bangladesh Atomic Energy Commission for their cordial support for the fulfillment of this research.

\section{REFERENCES}

[1] J. Militky, J. Vanicek, J. Krystufek, V., 'Modified Polyester Fibers', Elsevier, 1991.

[2] http://www.tstar.com/surface-modification. Accessed on Dec 25,2015 at 10:58PM

[3] Ammayappan, L. Eco-friendly Surface Modification of Wool Fiber for its improved Functionality: An Overview, Asian Journal of Textile 3(1):15-28, 2013.

[4] Osman, Mohamed, Eman, et al. 'The Effect of Both UV $\backslash$ Ozone and Chitosan on Natural Fabrics.' International Journal of Chemistry; Vol. 2, No. 2; August 2010.

[5] E. Heine, et al. 'Enzymes for wool Fibre Modification', Chapter 23, ISBN: 0-8412-3547-3, 1998, pp. 279-293.
[6] E. Heine, et al. Alternative Wool Treatment by means of Enzymes and Combined Processes, DWI-Report, (1996).

[7] https://en.wikipedia.org/wiki/Acid dye. Accessed on Dec 25, 2015 at 11:20PM.

[8] Bhuiyan, Rahman, M.A. et al. 'Cationization of Cotton Fiber by Chitosan and Its Dyeing with Reactive Dye without Salt.' Chemical and Materials Engineering; 2(4):96-100;2014

[9] KF El Talawy; M A Bendary El; AG Elhendawy; SM Hudson; Carbohydrate Polymers. 2005, 60, 421-430

[10] Jeon, Y.J, et al. 'Antimicrobial effect of chito-oligo saccharides produced by bioreactor'; Carbohydrate Polymers 2001, 44, 71-76

[11] RS Davidson; Y Xue. J. Soc. Dyers colour, 1994,110, 24-29.

[12] Struszczyk, Marcin, H.; 'Chitin and Chitosan', Part-II. Applications of Chitosan Polymer 2002, 47, nr6

[13] Pacual,E. and M.R.Julia,2001.The role of Chitosan in wool finishing. J.Biotechnol.89:289-296.

[14] Jocic, D, Svilchez, R Molina and Navarro et al. 'Effect of low temperature plasma and chitosan treatment on wool dyeing with Acid Red27'. J. Applied Polymer science, 97:2204-2214 (2005)

[15] Jamil S.M., et al. 'Metals removal from recovered base oil using Chitosan biopolymers.' 'J. Applied Polymer Science'.10:2725-2728(2010)

[16] Haji, Aminoddin, and Ahmad Mousavi Shoushtari. "Natural antibacterial finishing of wool fiber using plasma technology." Industria Textila 62.5 (2011): 244-247.

[17] Haji, Aminoddin, and Sayyed Sadroddin Qavamnia. "Response surface methodology optimized dyeing of wool with cumin seeds extract improved with plasma treatment." Fibers and Polymers 16.1 (2015): 46-53

[18] Bhatti, Ahmad, Ijaz; et al. "Effect of Radiation on Textile Dyeing" Available from http://www.intechopen. com/books/Title-dyeing/effect-of-radiation-on textile dyeing.

[19] Osman E. M., Micheal M. N; 'The Effect of Both UV $\backslash$ Ozone and Chitosan on Natural Fabrics' International Journal of Chemistry, Vol. 2, No. 2; August 2010.

[20] "Introduction to Infrared Spectroscopy", Available from www.researchgate.com, Accessed on Sep 25, 2016 at 11:36PM. 